\title{
Combining ability and breeding potential of oilseed rape advanced lines for some of important quantitative traits
}

\author{
Valiollah RAMEEH \\ Agronomic and Horticulture Crops Research Department, Mazandaran Agricultural and Natural Resources Research Center, \\ AREEO, Postal code: 48175556, Sari, Iran
}

\begin{abstract}
Information on estimates of combining ability of the promising lines of breeding material is important for evolving higher yielding varieties of oilseed rape (Brassica napus L.). An experiment was conducted to quantitatively examine the genetic parameters of phenological traits, plant height, pods on main raceme, pods per plant and seed yield for eight oilseed rape genotypes using a half-diallel crosses. The result of the diallel analysis revealed significant mean squares of general and specific combining abilities (GCA and SCA) for all studied traits, indicating the importance of additive and non-additive genetic effects for these traits. On the other hand estimation of high narrow-sense heritability estimates for days to flowering, duration of flowering and pods on main raceme, indicated the prime importance of additive genetic effects for these traits. L420 and L401 with significant negative GCA effects for days to flowering and days to maturity were suitable for yielding early maturity combinations. L41, Zafar and L22 with significant positive GCA effects for seed yield were superior parents for increasing seed yield. The crosses with significant positive SCA effects for seed yield had at least one parent with significant positive GCA effects for this trait. The crosses including L41 $\times$ L22, L41 $\times$ LF2, Zafar $\times$ L22 and Zafar $\times$ L420 with seed yield of $3421.7,3400,3348.1$ and $3311.3 \mathrm{~kg} \mathrm{ha}^{-1}$ could be promising for determination of superior recombinants for high seed yield coupled with other growth characters in advanced generations of segregation.
\end{abstract}

Key words: Additive genetic effects, Brassica napus, degree of dominance, combining ability, heritability, oilseed rape, yield.

\section{INTRODUCTION}

Oilseed rape or canola (Brassica napus L.) is an important oil seed crop of the world (Downey and Rimer 1993) and due to its autumn cultivation in Iran and therefore low need of irrigation, it plays a major role in catering edible oil. Hence it is necessary to develop the new ideotype varieties or hybrids of oilseed rape with high yield components. Seed yield of canola (B. napus) is a quantitative trait, which is largely influenced by the different environmental effects and thus in most of the cases it has low heritability (Habekotte 1997; Diepenbrock 2000; Rameeh 2010; Rameeh 2015; Amiri-Oghana et al. 2016). Exploitation of genetic variability in any crop species is considered to be critical for making further genetic improvement in seed yield as well as other economically important traits (Mahmood et al. 2003; Ishaq et al. 2016). Inter- and intraspecies crosses of Brassica are suitable way to make genetic variations and develop new varieties (Brandle and McVetty 1990; Enqvist and Becker 1991; Qian et al. 2007; Rameeh 2011). Heterosis is commercially exploited in oilseed rape and its potential use has been demonstrated in turnip rape (B. rapa L.) and Indian mustard (B. juncea L.) for most agronomic traits (Teklwold and Becker 2005; Zhang and Zhu 2006). In oilseed rape breeding program for hybrid and open pollinated varieties, general and specific combining ability effects (GCA and SCA) are important indicators of the

${ }^{*}$ Correspondence to:

E-mail:vrameeh@gmail.com, 
potential of inbred lines in hybrid combinations. By using diallel crosses manners, and other genetic designs significant GCA and SCA effects of phenological traits, seed yield and other yield associated traits were reported in oilseed rape (Shen et al. 2002; Nassimi, et al. 2006b; Wang et al. 2007). Flowering is the most critical developmental stage influencing the yield of this crop (Faraj et al. 2008). The unset of flower initiation can have strong influence on flower, pod and seed number (Diepenbrock 2000; Downey and Rimer 1993; Yasari and Patwardhan 2006; Rameeh 2017). Habekotte (1997) used a sensitivity analysis within a crop growth model to study options for increasing seed yield in winter oilseed rape. The most promising crop type for high seed yield combined late maturity with early flowering (Downey and Rimer 1993). Early flowering in Brassica can provide adequate time for seed formation process and can certainly cause early maturity and higher yields, therefore negative combining ability and heterosis are desirable for days to flowering. In earlier studies on spring cultivars of oilseed rape (Huang et al. 2010; Rameeh 2011; Liton et al. 2017) were stressed the important role of GCA and SCA effects for days to flowering but due to high heritability estimates for this trait in these reports, the prime importance of GCA effects were emphasized. Likewise, studies with winter cultivars of this species (Amiri-Oghana et al. 2009; Sabaghnia et al. 2010) showed both additive and dominance gene effects to have a significant role in the inheritance of flowering time. Significant negative GCA and SCA effects were reported for days to flowering and plant height. Significant GCA and SCA effects were reported for seed yield in oilseed rape (Rameeh, 2010) and other Brassica species (Teklwold and Becker 2005; Singh et al. 2010).

The objectives of the present study were to identify general and specific combining abilities and narrow-sense heritability for phenological traits, plant height and seed yield in adapted spring oilseed rape advanced lines.

\section{MATERIALS AND METHODS}

Eight diverse spring oilseed rape (B. napus) advanced lines including L41, Zafar, L56, L31, L22, LF2, L420 and L401 were crossed in half-diallel scheme during 2010-11 (Table 1). Twenty eight F1s along with their parents were grown in a randomized complete block design with three replications at Biekol Agriculture Research Station, located in Neka, Iran $\left(53^{\circ}, 13^{\prime} \mathrm{E}\right.$ longitude and $36^{\circ} 43^{\prime} \mathrm{N}$ latitude, $15 \mathrm{~m}$ above sea level) during winter 2011-12. Each plot consisted of four rows $5 \mathrm{~m}$ long and $40 \mathrm{~cm}$ apart. The distance between plants on each row was $5 \mathrm{~cm}$ resulting in approximately 300 plants per plot, which were sufficient for F1 genetic analysis. The soil was classified as a deep loam soil (Typic Xerofluents, USDA classification) which contained an average of $280 \mathrm{~g}$ clay $\mathrm{kg}^{-1}, 560 \mathrm{~g}$ silt kg-1, $160 \mathrm{~g}^{-1}$ sand $\mathrm{kg}^{-1}$, and $22.4 \mathrm{~g}$ organic matter $\mathrm{kg}^{-1}$ with a $\mathrm{pH}$ of 7.3. Soil samples were found to have $45 \mathrm{~kg} \mathrm{ha}^{-1}$ (mineral $\mathrm{N}$ in the upper $30-\mathrm{cm}$ profile). Fertilizers were applied at the rates of 100: 50: $90 \mathrm{~kg} \mathrm{ha}^{-1}$ of N: P: K, respectively. All the plant protection measures were adopted to make the crop free from insects. Seed yield (adjusted to $\mathrm{kg} \mathrm{ha}^{-1}$ ) was recorded based on three middle rows of each plot. The data were recorded on ten randomly selected plants of each entry of each replication for days to flowering, duration of flowering and days to maturity and plant height, pods on main raceme and pods per plant. The combining ability analysis was performed using mean values their F1 generations along with parents by using Griffing's method 2 with mixed B model (Griffing 1956). The statistical t-student test was applied to examine the effects of general combining ability (GCA) and specific combining ability (SCA). All the analyses were performed using MS-Excel and SAS soft wares (Zhang and Kang 1997).

\section{RESULTS AND DISCUSSIONS}

\section{Analysis of variance}

Significant mean squares of genotypes for number of days to flowering, duration of flowering, number of days to maturity, plant height, number of pods on main raceme, number of pods per plant and seed yield indicated a sufficient genetic variation among the parents and their crosses for the studied traits and thus enabling the genetic analysis (Table 2). Significant mean squares of general and specific combining ability (GCA and SCA) mean squares for all the traits are indicating the importance of additive and non-additive genetic effects for controlling the traits. However. Significant ratio of GCA to SCA mean square and high narrow-sense heritability estimates for days to flowering, duration of flowering and number of pods on main raceme implied that inheritances these traits are strongly associated with additive gene actions. Similarly, earlier researchers (Huang et al. 2010; Sabaghnia et al. 2010; Rameeh 2011) reported the important

Table 1: Name and origin of oilseed rape genotypes.

\begin{tabular}{|c|c|c|c|c|}
\hline Type & Origin & Pedigree & Genotype & Genotype no. \\
\hline Spring-open-pollinated & Iran-Mazandaran & RGS003 $\times 308$ & L41 & 1 \\
\hline Spring-open-pollinated & Iran-Mazandaran & $19 \mathrm{H} \times$ Sarigol & Zafar & 2 \\
\hline Spring-open-pollinated & Iran-Mazandaran & RW $\times$ RGS003 & L56 & 3 \\
\hline Spring-open-pollinated & Iran-Mazandaran & SLM046 $\times 308$ & L31 & 4 \\
\hline Spring-open-pollinated & Iran-Mazandaran & Zarfam $\times 401$ & L22 & 5 \\
\hline Spring-open-pollinated & Iran-Mazandaran & Zarfam $\times 308$ & LF2 & 6 \\
\hline Spring-open-pollinated & Iran-Mazandaran & RGS003 $\times 420$ & L420 & 7 \\
\hline Spring-open-pollinated & Iran-Mazandaran & RGS003 $\times 420$ & L401 & 8 \\
\hline
\end{tabular}


Table 2: Half-diallel analysis for phenological traits, yield components and seed yield in eight oilseed rape genotypes.

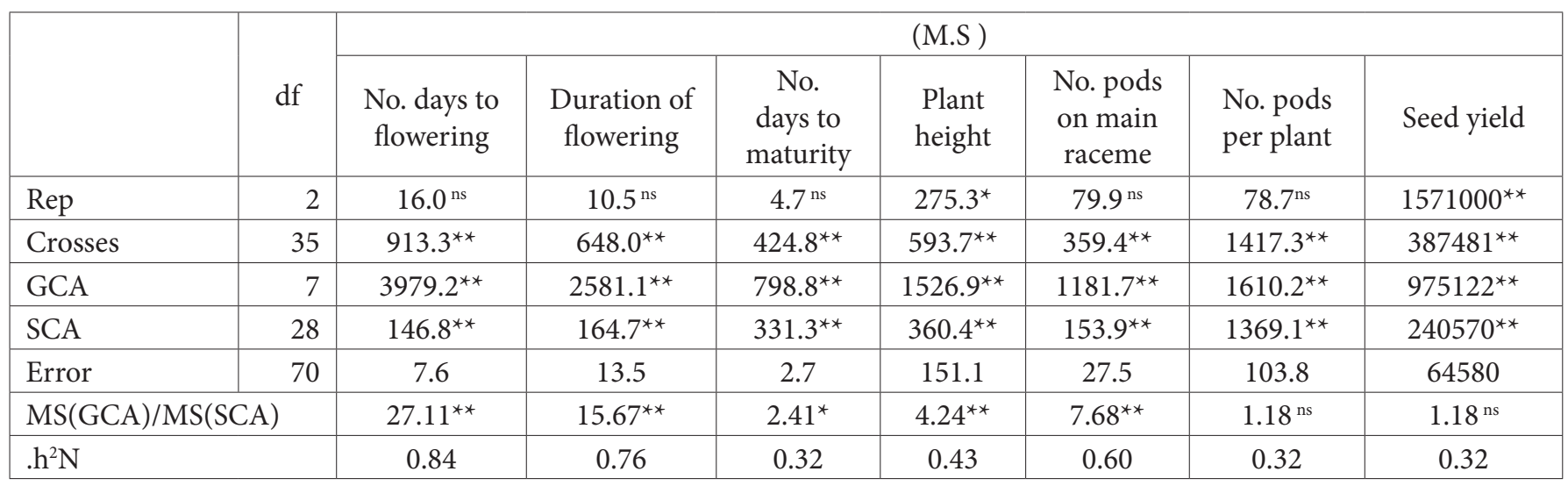

ns, ${ }^{*}$ and ${ }^{* *}$ : Not- significant, significant at $5 \%$ and $1 \%$ levels of probability, respectively.

role of additive genetic effects for phenological traits and also the importance of non-additive effects for seed yield.

\section{General combining ability and performance means of the parents}

Considering the negative GCA values for days to flowering, the genotypes L420 and L401 could be distinguished for its significantly different value. These parents had also a significant positive GCA effects for duration of flowering (Table 3). The mean values of the number days to flowering varied from 83 to 113 days in L420 and L22, respectively and the parents L420 and L401 with 83 and 84 days exhibited low mean values of this trait (Table 4). Significant positive correlation GCA effects of parents for the number of days to flowering with days to maturity and pods on main raceme (Table 5), concluded that, GCA effect of days to flowering is good criterion for improving GCA effect of days to maturity and pods on main raceme. Due to important positive effect of duration of flowering on pod formation, L420 and L401 with high mean values and also significant positive GCA effect of this trait will be preferred. Significant negative correlation was detected between GCA effect of parents for days to flowering and duration of flowering The parents with significant negative GCA effects for the number of days to flowering had also significant negative GCA effects of the number of days to maturity. Having studied several quantitative and qualitative traits of oilseed rape lines, cultivars and hybrids, Marjanović - Jeromela et al. (2007) reported different values of plant height. The parents L31, LF2 and L401 with significant negative GCA effects for plant height were suitable for the decreasing this trait and their mean performances for this trait were 149,153 and $155 \mathrm{~cm}$, respectively. The number of pods on main raceme ranged from 42 in L401 and 56 in L41 and Zafar and these parents had also significant positive GCA effects for this trait. The number of pods per plant as prime important yield component had considerable effect on seed yield, therefore the parents L41, Zafar and L22 with significant positive GCA effects of this trait were preferred. Among the parents, L41, Zafar and L22 had significant GCA effect for seed yield and most of parents with positive GCA effects of the number of pods per plant had positive GCA effect of this trait. This finding is in agreement with the results of Rameeh (2010) and Sabaghnia et al. (2009) reports for significant positive GCA effects of parents for seed yield in oilseed rape.

Table 3: General combining ability effects of half-diallel analysis for phenological traits, yield components and seed yield in eight oilseed rape genotypes.

\begin{tabular}{|c|c|c|c|c|c|c|c|}
\hline Parents & $\begin{array}{l}\text { No. days to } \\
\text { flowering }\end{array}$ & $\begin{array}{c}\text { Duration of } \\
\text { flowering }\end{array}$ & $\begin{array}{c}\text { No. days to } \\
\text { maturity }\end{array}$ & $\begin{array}{l}\text { Plant } \\
\text { height }\end{array}$ & $\begin{array}{l}\text { No. pods on } \\
\text { main raceme }\end{array}$ & $\begin{array}{l}\text { No. pods per } \\
\text { plant }\end{array}$ & $\begin{array}{l}\text { Seed } \\
\text { yield }\end{array}$ \\
\hline $\mathrm{L} 41$ & $5.4^{\star *}$ & $-4.53^{\star *}$ & $2.25^{\star *}$ & $6.34^{* *}$ & $5.50^{* *}$ & $10.72^{\star *}$ & $184.68^{\star *}$ \\
\hline Zafar & $5.1^{\star *}$ & $-3.93^{\star *}$ & $1.28^{\star *}$ & $9.15^{\star *}$ & $5.93^{\star *}$ & $9.31^{\star *}$ & $147.26^{* *}$ \\
\hline L56 & $8.6^{* *}$ & $-6.33^{\star *}$ & $1.82^{* *}$ & $4.51^{\star}$ & $5.12^{\star *}$ & $-8.78^{\star *}$ & $27.47 \mathrm{~ns}$ \\
\hline L31 & $4.0^{\star *}$ & $-6.00^{* *}$ & $5.62^{\star *}$ & $-10.37^{\star \star}$ & -1.20 & $0.33 \mathrm{~ns}$ & $-291.27^{\star \star}$ \\
\hline L22 & $9.9^{* *}$ & $-5.73^{\star *}$ & $5.32^{\star *}$ & -1.50 & $5.64^{\star *}$ & $3.59^{\star}$ & $187.30^{* *}$ \\
\hline LF2 & $3.9^{* *}$ & $-3.27^{\star \star}$ & $-1.92^{\star *}$ & $-5.97^{\star \star}$ & $-6.95^{\star *}$ & $-2.85 n s$ & $9.99 \mathrm{~ns}$ \\
\hline L420 & $-18.8^{\star \star}$ & $13.77^{\star *}$ & $-4.98^{\star \star}$ & $4.58^{\star}$ & $-5.59^{\star *}$ & $-6.17^{\star *}$ & $-44.01 \mathrm{~ns}$ \\
\hline L401 & $-17.9^{\star *}$ & $16.03^{* *}$ & $-9.38^{* *}$ & $-6.76^{* *}$ & $-8.44^{\star *}$ & $-6.16^{* *}$ & $-221.41^{\star *}$ \\
\hline
\end{tabular}

ns, ${ }^{*}$ and ${ }^{* *}$ : Not -significant, significant at $5 \%$ and $1 \%$ levels of probability, respectively. 
Table 4: Mean values of half-diallel analysis for phenological traits, yield components and seed yield in eight oilseed rape genotypes.

\begin{tabular}{|c|c|c|c|c|c|c|c|}
\hline Parents & $\begin{array}{c}\text { No. days to } \\
\text { flowering }\end{array}$ & $\begin{array}{c}\text { Duration of } \\
\text { flowering }\end{array}$ & $\begin{array}{c}\text { No. days to } \\
\text { maturity }\end{array}$ & $\begin{array}{c}\text { Plant height } \\
(\mathrm{cm})\end{array}$ & $\begin{array}{c}\text { No. pods } \\
\text { on main } \\
\text { raceme }\end{array}$ & $\begin{array}{c}\text { No. pods } \\
\text { per plant }\end{array}$ & $\begin{array}{c}\text { Seed yield } \\
\left(\mathrm{kg} \text { ha }{ }^{-1}\right.\end{array}$ \\
\hline L41 & 107 & 57 & 208 & 168 & 56 & 140 & 2929.2 \\
\hline Zafar & 107 & 58 & 207 & 170 & 56 & 137 & 2925.0 \\
\hline L56 & 110 & 55 & 207 & 164 & 54 & 130 & 2866.7 \\
\hline L31 & 106 & 55 & 212 & 149 & 48 & 119 & 2187.5 \\
\hline L22 & 113 & 55 & 212 & 158 & 55 & 158 & 3120.8 \\
\hline LF2 & 106 & 58 & 205 & 153 & 44 & 112 & 2737.5 \\
\hline L420 & 83 & 76 & 199 & 164 & 44 & 130 & 2612.5 \\
\hline L401 & 84 & 78 & 198 & 155 & 42 & 94 & 2083.3 \\
\hline LSD( $\alpha=0.05)$ & 4.41 & 5.88 & 2.63 & 19.67 & 8.39 & 16.64 & 414.99 \\
\hline LSD( $\alpha=0.01)$ & 5.78 & 7.71 & 3.45 & 25.79 & 11.00 & 22.13 & 551.93 \\
\hline
\end{tabular}

Table 5: Pearsons correlation coefficient among GCA effects of parents and SCA effects of crosses for phenological traits, yield components and seed yield.

\begin{tabular}{|c|c|c|c|c|c|c|c|}
\hline \multicolumn{8}{|c|}{$\operatorname{GCA}(n=8)$} \\
\hline & $\begin{array}{c}\text { No. days to } \\
\text { flowering }\end{array}$ & $\begin{array}{c}\text { Duration of } \\
\text { flowering }\end{array}$ & $\begin{array}{l}\text { No. days to } \\
\text { maturity }\end{array}$ & $\begin{array}{l}\text { Plant } \\
\text { height }\end{array}$ & $\begin{array}{l}\text { No. pods } \\
\text { on main } \\
\text { raceme }\end{array}$ & $\begin{array}{l}\text { No. pods } \\
\text { per plant }\end{array}$ & $\begin{array}{l}\text { Seed } \\
\text { yield }\end{array}$ \\
\hline No. days to flowering & 1 & & & & & & \\
\hline Duration of flowering & $-0.98^{\star *}$ & 1 & & & & & \\
\hline No. days to maturity & $0.87^{\star \star}$ & $-0.91^{\star *}$ & 1 & & & & \\
\hline Plant height & $0.12^{\mathrm{ns}}$ & $0.11^{\mathrm{ns}}$ & $0.07^{\mathrm{ns}}$ & 1 & & & \\
\hline No. pods on main raceme & $0.75^{\star}$ & $-0.72^{*}$ & $0.76^{*}$ & $0.60^{\mathrm{ns}}$ & 1 & & \\
\hline No. pods per plant & $0.48^{\mathrm{ns}}$ & -0.48 & $0.51^{\mathrm{ns}}$ & 0.37 & $0.61^{\mathrm{ns}}$ & 1 & \\
\hline Seed yield & $0.51^{\mathrm{ns}}$ & -0.43 & $0.35^{\mathrm{ns}}$ & $0.73^{*}$ & $0.69^{\mathrm{ns}}$ & $0.57^{\mathrm{ns}}$ & 1 \\
\hline \multicolumn{8}{|c|}{$\operatorname{SCA}(n=28)$} \\
\hline & $\begin{array}{c}\text { No. days to } \\
\text { flowering }\end{array}$ & $\begin{array}{c}\text { Duration of } \\
\text { flowering }\end{array}$ & $\begin{array}{l}\text { No. days to } \\
\text { maturity }\end{array}$ & $\begin{array}{l}\text { Plant } \\
\text { height }\end{array}$ & $\begin{array}{l}\text { No. pods } \\
\text { on main } \\
\text { raceme }\end{array}$ & $\begin{array}{l}\text { No. pods } \\
\text { per plant }\end{array}$ & $\begin{array}{l}\text { Seed } \\
\text { yield }\end{array}$ \\
\hline No. days to flowering & 1 & & & & & & \\
\hline Duration of flowering & $-0.75^{\star *}$ & 1 & & & & & \\
\hline No. days to maturity & $0.59^{* *}$ & $0.61^{\star \star}$ & 1 & & & & \\
\hline Plant height & $-0.09^{\mathrm{ns}}$ & $0.38^{\star}$ & $0.04^{\mathrm{ns}}$ & 1 & & & \\
\hline No. pods on main raceme & $-0.15^{\mathrm{ns}}$ & $0.33^{\mathrm{ns}}$ & $-0.07^{\mathrm{ns}}$ & $0.71^{\star \star}$ & 1 & & \\
\hline No. pods per plant & $-0.14^{\mathrm{ns}}$ & $0.08^{\mathrm{ns}}$ & $0.02^{\mathrm{ns}}$ & $0.56^{\star *}$ & $0.65^{\star *}$ & 1 & \\
\hline Seed yield & $-0.18^{\mathrm{ns}}$ & $0.05^{\mathrm{ns}}$ & $-0.04^{\mathrm{ns}}$ & $0.27^{\mathrm{ns}}$ & $0.35^{\mathrm{ns}}$ & $0.66^{\star *}$ & 1 \\
\hline
\end{tabular}

${ }^{\star}$ and ${ }^{* *}$ : Significant at $5 \%$ and $1 \%$ levels of probability, respectively.

\section{Specific combining ability effects of the crosses}

Out of 28 crosses, 13 crosses had significant negative SCA effects of No. days days to flowering (Table6). Most of the crosses with significant negative SCA effect of No. days days to flowering had at least one parent with significant negative GCA effect for this trait. The crosses L420×L401,
Zafar $\times$ L401, L41 $\times$ L420, L56 $\times$ L420, L31 $\times$ L420 and L31 $\times$ L401 with $66,78,84,84,83$ and 81 days to flowering had low mean values of this trait (Table 7 ), were also good combinations. SCA effects of combinations for No. days to flowering was significant negative correlated to No. days to maturity, therefore SCA effect of No. days to flowering is good selection criterion for improving No. days to maturity. The crosses L41×L401, Zafar×L401, L56×L401, L31× L420, L22 
$\times$ L420, LF $2 \times$ L401 and L420×L401 with 79, 90, 78, 77, 76, 78 and 88 days of flowering had also significant positive SCA effects for this trait were considered as merit combinations. The crossesincluding L41 $\times$ L420, Zafar $\times$ L420, Zafar $\times$ L401, L56 $\times$ L420 and LF $2 \times$ L401 with low mean values of days to maturity (188, 188, 184, 189 and 178 days, respectively) also high significant negative SCA effect of No. days to maturity $(-16.03,-14.39,-14.66,-13.93$ and -17.13 , respectively) were suitable combinations for improving this trait. The genotypes with low mean values of plant height will have high tolerance to lodging, therefore the crosses including L41 $\times$ L31, L56 $\times$ L401 and LF2 $\times$ L401 with significant negative SCA effect for plant height were valuable combinations for improving this trait. The knowledge of yield components helps breeders to select genotypes and methods suitable for achieving specific objectives in rapeseed breeding. It is also desirable to know other traits and the genetic rules regulating their inheritance since these traits are associated with yield components (Teklwold and Becker, 2005; Zhang and Zhu, 2006). High positive SCA values of No of pods on main raceme, which were significantly different from the other values, were registered in $\mathrm{L} 41 \times \mathrm{LF} 2, \mathrm{~L} 41 \times \mathrm{L} 420$, Zafar $\times$ L401 and L31 $\times$ L401. Significant negative correlation exhibited between SCA effects of combinations for No. of pods per plant and seed yield (Table 5), therefore SCA effect of combinations for the No. of pods per plant is good selection criterion for improving seed yield of combinations. Seed yield per plant is a highly variable trait, mainly because it depends on all other yield components. This complex trait is controlled by a large number of genes, whose expression is strongly affected by environmental conditions. In this study, different values of seed yield per plant were registered, from $2196.7 \mathrm{~kg} \mathrm{ha}^{-1}$ in L56 $\times$ L420 to $3400 \mathrm{~kg} \mathrm{ha}^{-1} \mathrm{~L} 41 \times \mathrm{LF} 2$. The crosses L41 $\times$ LF2, Zafar $\times$ L22, Zafar $\times$ L420 and L56 $\times$ L22 with seed yield of $3400,3348.1,3311.3$ and $3278.4 \mathrm{~kg} \mathrm{ha}^{-1}$ were high potential combinations for seed yield. Hybrid combinations L41 $\times$ LF2, Zafar $\times$ L420, L56×L22, L31 $\times$ L401and LF2 $\times$ L420 had highest SCA values, which were highly significant in relation to the SCA values of the other hybrid combinations. The crosses L41 $\times$ LF2, Zafar $\times$ L420, L56 $\times$ L22, L31 $\times$ L401 and LF $2 \times$ L420 with significant positive SCA effects for seed yield were suitable combinations for improving this trait. It had been observed before that crossing a parent with high GCA values with a parent with low GCA values may produce a hybrid combination with high SCA values (Marjanović Jeromela, et al., 2007).

Table 6: Mean values of half-diallel analysis for phenological traits, yield components and seed yield of eight oilseed rape genotypes.

\begin{tabular}{|c|c|c|c|c|c|c|c|}
\hline Crosses & $\begin{array}{l}\text { No. days to } \\
\text { flowering }\end{array}$ & $\begin{array}{l}\text { Duration of } \\
\text { flowering }\end{array}$ & $\begin{array}{l}\text { No. days to } \\
\text { maturity }\end{array}$ & $\begin{array}{l}\text { Plant height } \\
(\mathrm{cm})\end{array}$ & $\begin{array}{l}\text { No. pods on } \\
\text { main raceme }\end{array}$ & $\begin{array}{l}\text { No. pods per } \\
\text { plant }\end{array}$ & $\begin{array}{l}\text { Seed yield } \\
\left(\mathrm{kg} \mathrm{ha}^{-1}\right)\end{array}$ \\
\hline L41 × Zafar & 114 & 46 & 214 & 167.2 & 55 & 145 & 2839.2 \\
\hline $\mathrm{L} 41 \times \mathrm{L} 56$ & 118 & 49 & 214 & 173.7 & 62 & 136 & 3180.8 \\
\hline $\mathrm{L} 41 \times \mathrm{L} 31$ & 111 & 47 & 213 & 141.1 & 48 & 138 & 2315.9 \\
\hline $\mathrm{L} 41 \times \mathrm{L} 22$ & 113 & 53 & 211 & 164.3 & 63 & 156 & 3412.7 \\
\hline $\mathrm{L} 41 \times \mathrm{LF} 2$ & 104 & 65 & 206 & 169.5 & 62 & 172 & 3400.0 \\
\hline $\mathrm{L} 41 \times \mathrm{L} 420$ & 84 & 73 & 188 & 188.1 & 57 & 162 & 3000.0 \\
\hline $\mathrm{L} 41 \times \mathrm{L} 401$ & 98 & 79 & 207 & 173.7 & 47 & 154 & 2908.3 \\
\hline Zafar $\times$ L56 & 121 & 46 & 213 & 183.6 & 62 & 139 & 3031.1 \\
\hline Zafar $\times$ L31 & 113 & 49 & 217 & 155.8 & 49 & 129 & 2673.8 \\
\hline Zafar $\times$ L22 & 113 & 56 & 212 & 162.4 & 62 & 145 & 3348.1 \\
\hline Zafar $\times$ LF2 & 114 & 57 & 211 & 165.6 & 54 & 146 & 2512.5 \\
\hline Zafar $\times$ L420 & 84 & 74 & 188 & 163.9 & 45 & 173 & 3311.3 \\
\hline Zafar $\times$ L401 & 78 & 90 & 184 & 192.5 & 65 & 177 & 2975.0 \\
\hline $\mathrm{L} 56 \times \mathrm{L} 31$ & 119 & 48 & 215 & 156.2 & 56 & 139 & 2302.5 \\
\hline $\mathrm{L} 56 \times \mathrm{L} 22$ & 117 & 51 & 212 & 171.4 & 61 & 148 & 3287.4 \\
\hline L56 $\times$ LF2 & 114 & 51 & 206 & 153.6 & 48 & 124 & 2915.4 \\
\hline $\mathrm{L} 56 \times \mathrm{L} 420$ & 84 & 74 & 189 & 151.8 & 46 & 105 & 2695.8 \\
\hline $\mathrm{L} 56 \times \mathrm{L} 401$ & 86 & 78 & 194 & 147.7 & 36 & 96 & 2196.7 \\
\hline $\mathrm{L} 31 \times \mathrm{L} 22$ & 112 & 56 & 215 & 150.9 & 52 & 145 & 2626.9 \\
\hline $\mathrm{L} 31 \times \mathrm{LF} 2$ & 112 & 49 & 215 & 149.8 & 44 & 172 & 2511.7 \\
\hline $\mathrm{L} 31 \times \mathrm{L} 420$ & 83 & 77 & 189 & 147.6 & 34 & 112 & 2537.5 \\
\hline $\mathrm{L} 31 \times \mathrm{L} 401$ & 81 & 68 & 214 & 144.5 & 47 & 166 & 2812.5 \\
\hline $\mathrm{L} 22 \times \mathrm{LF} 2$ & 117 & 49 & 217 & 147.2 & 37 & 112 & 2727.7 \\
\hline $\mathrm{L} 22 \times \mathrm{L} 420$ & 98 & 76 & 202 & 166.2 & 55 & 106 & 2413.7 \\
\hline $\mathrm{L} 22 \times \mathrm{L} 401$ & 117 & 49 & 214 & 144.3 & 47 & 143 & 2883.3 \\
\hline $\mathrm{LF} 2 \times \mathrm{L} 420$ & 94 & 66 & 207 & 151.9 & 39 & 131 & 3079.6 \\
\hline $\mathrm{LF} 2 \times \mathrm{L} 401$ & 83 & 78 & 178 & 134.4 & 38 & 125 & 2546.4 \\
\hline $\mathrm{L} 420 \times \mathrm{L} 401$ & 66 & 88 & 213 & 160.7 & 34 & 125 & 2365.4 \\
\hline $\operatorname{LSD}(\alpha=0.05)$ & 4.41 & 5.88 & 2.63 & 19.67 & 8.39 & 16.64 & 414.99 \\
\hline $\operatorname{LSD}(\alpha=0.01)$ & 5.78 & 7.71 & 3.45 & 25.79 & 11.00 & 22.13 & 551.93 \\
\hline
\end{tabular}




\section{CONCLUSIONS}

In general pods Significant ratio of GCA to SCA mean square and high narrow-sense heritability estimates for days to flowering, duration of flowering and number of pods on main raceme implied that inheritances these traits are strongly associated with additive gene actions. Among the parents, L41, Zafar and L22 with significant positive GCA effects for seed yield were superior combiners for improving this trait. The crosses with significant positive SCA effects for seed yield had at least one parent with significant positive GCA effects for this trait. The crosses including $\mathrm{L} 41 \times \mathrm{L} 22$, L41 $\times$ LF2, Zafar $\times$ L22 and Zafar $\times$ L420 with seed yield of
$3421.7,3400,3348.1$ and $3311.3 \mathrm{~kg} \mathrm{ha}^{-1}$ could be promising for determination of superior recombinants for high seed yield coupled with other growth characters in advanced generations of segregation.

\section{ACKNOWLEDGEMENTS}

The author wish to thank from Agricultural and Natural Resources Research and Education Center of Mazandaran and Seed and Plant Improvement Institute (SPII) for providing genetic materials and facility for conducting the experiment.

Table 7: Specific combining ability effects of half-diallel analysis for phenological traits, yield components and seed yield in eight oilseed rape genotypes.

\begin{tabular}{|c|c|c|c|c|c|c|c|}
\hline Crosses & $\begin{array}{c}\text { No. days to } \\
\text { flowering }\end{array}$ & $\begin{array}{c}\text { Duration of } \\
\text { flowering }\end{array}$ & $\begin{array}{c}\text { No. days to } \\
\text { maturity }\end{array}$ & $\begin{array}{l}\text { Plant } \\
\text { height }\end{array}$ & $\begin{array}{l}\text { No. pods on } \\
\text { main raceme }\end{array}$ & $\begin{array}{l}\text { No. pods per } \\
\text { plant }\end{array}$ & Seed yield \\
\hline L41 × Zafar & 1.36 & $-7.35^{\star \star}$ & $4.04^{\star \star}$ & -8.70 & $-6.25^{\star *}$ & $-12.08^{\star}$ & $-278.1^{\star}$ \\
\hline $\mathrm{L} 41 \times \mathrm{L} 56$ & 2.16 & -1.95 & $3.84^{\star \star *}$ & 2.41 & 1.48 & $-3.36 n s$ & $183.2 \mathrm{~ns}$ \\
\hline $\mathrm{L} 41 \times \mathrm{L} 31$ & -0.54 & $-4.28^{\star}$ & -1.29 & $-15.28^{\star}$ & $-6.36^{\star *}$ & $-9.84 n s$ & $-362.9^{* *}$ \\
\hline $\mathrm{L} 41 \times \mathrm{L} 22$ & $-4.47^{\star \star}$ & 1.79 & $-2.99^{* *}$ & -0.98 & 2.30 & $4.51 \mathrm{~ns}$ & $255.3 \mathrm{~ns}$ \\
\hline $\mathrm{L} 41 \times \mathrm{LF} 2$ & $-7.11^{\star *}$ & $11.65^{\star *}$ & -0.43 & 8.69 & $13.43^{\star \star}$ & $26.51^{\star *}$ & $420.0^{\star *}$ \\
\hline $\mathrm{L} 41 \times \mathrm{L} 420$ & $-5.17^{\star \star}$ & 2.62 & $-16.03^{\star \star}$ & $16.74^{\star}$ & $7.90^{\star *}$ & $20.23^{\star \star}$ & $74.0 \mathrm{~ns}$ \\
\hline $\mathrm{L} 41 \times \mathrm{L} 401$ & $8.33^{* *}$ & $5.69^{* *}$ & $8.04^{\star \star}$ & $13.71^{\star}$ & 0.55 & $11.79^{*}$ & $159.7 \mathrm{~ns}$ \\
\hline Zafar $\times$ L56 & $5.46^{* *}$ & $-5.21^{\star *}$ & $3.47^{\star \star}$ & 9.56 & 1.45 & $0.84 \mathrm{~ns}$ & $71.0 \mathrm{~ns}$ \\
\hline Zafar $\times$ L31 & 2.09 & -2.88 & $3.34^{\star *}$ & -3.43 & $-5.29^{\star}$ & $-17.80^{\star *}$ & $32.4 \mathrm{~ns}$ \\
\hline Zafar $\times$ L22 & $-3.84^{* *}$ & $3.85^{\star}$ & -1.36 & -5.63 & 0.81 & $-4.69 \mathrm{~ns}$ & $228.1 \mathrm{~ns}$ \\
\hline Zafar $\times$ LF2 & $2.86^{\star}$ & 3.05 & $4.87^{\star *}$ & 2.01 & $5.83^{\star}$ & $2.35 \mathrm{~ns}$ & $-430.1^{\star *}$ \\
\hline Zafar $\times$ L420 & $-4.87^{\star \star}$ & 2.69 & $-14.39^{\star *}$ & -10.21 & $-5.13^{\star}$ & $32.37^{\star *}$ & $422.7^{\star \star}$ \\
\hline Zafar $\times$ L401 & $-11.71^{\star *}$ & $16.42^{* *}$ & $-14.66^{\star *}$ & $29.70^{\star *}$ & $17.69^{\star *}$ & $36.22^{* *}$ & $263.8 \mathrm{~ns}$ \\
\hline $\mathrm{L} 56 \times \mathrm{L} 31$ & $3.89^{* *}$ & -0.81 & 1.14 & 1.65 & 2.88 & $10.22 \mathrm{~ns}$ & $-219.1 \mathrm{~ns}$ \\
\hline $\mathrm{L} 56 \times \mathrm{L} 22$ & $-3.71^{\star *}$ & 1.92 & -1.89 & 7.94 & 0.24 & $16.13^{* *}$ & $287.3^{*}$ \\
\hline $\mathrm{L} 56 \times \mathrm{LF} 2$ & -0.67 & -0.88 & 0.01 & -5.39 & 0.30 & $-1.39 \mathrm{~ns}$ & $92.6 \mathrm{~ns}$ \\
\hline $\mathrm{L} 56 \times \mathrm{L} 420$ & $-8.41^{\star *}$ & $4.75^{\star}$ & $-13.93^{\star *}$ & $-17.67^{\star *}$ & -3.43 & $-17.27^{\star *}$ & $-73.0 \mathrm{~ns}$ \\
\hline $\mathrm{L} 56 \times \mathrm{L} 401$ & $-7.24^{\star *}$ & $7.15^{\star *}$ & $-5.19^{\star *}$ & -10.50 & $-10.71^{\star *}$ & $-26.12^{\star *}$ & $-394.8^{\star *}$ \\
\hline $\mathrm{L} 31 \times \mathrm{L} 22$ & $-4.41^{\star *}$ & $5.92^{\star *}$ & $-2.36^{\star *}$ & 2.36 & -1.70 & $3.96 \mathrm{~ns}$ & $-54.5 \mathrm{~ns}$ \\
\hline $\mathrm{L} 31 \times \mathrm{LF} 2$ & 2.29 & -3.21 & $4.54^{* *}$ & 5.76 & 2.52 & $36.93^{\star *}$ & $7.6 \mathrm{~ns}$ \\
\hline $\mathrm{L} 31 \times \mathrm{L} 420$ & $-4.11^{\star *}$ & $7.75^{\star *}$ & $-18.06^{* *}$ & -7.05 & $-9.00^{* *}$ & $-19.75^{\star *}$ & $87.4 \mathrm{~ns}$ \\
\hline $\mathrm{L} 31 \times \mathrm{L} 401$ & $-6.94^{* *}$ & -3.51 & $11.34^{\star *}$ & 1.22 & $6.75^{\star *}$ & $34.30^{\star *}$ & $539.8^{\star *}$ \\
\hline $\mathrm{L} 22 \times \mathrm{LF} 2$ & 1.03 & $-3.81^{\star}$ & $6.84^{\star *}$ & -5.78 & $-11.75^{\star *}$ & $-26.29^{\star *}$ & $-255.0 \mathrm{~ns}$ \\
\hline $\mathrm{L} 22 \times \mathrm{L} 420$ & $4.63^{\star *}$ & $6.82^{\star *}$ & $-4.76^{\star *}$ & 2.71 & $5.03^{*}$ & $-28.14^{\star *}$ & $-515.0^{* *}$ \\
\hline $\mathrm{L} 22 \times \mathrm{L} 401$ & $22.79^{* *}$ & $-22.45^{\star *}$ & $11.97^{\star *}$ & -7.85 & -0.12 & $8.11 \mathrm{~ns}$ & $132.1 \mathrm{~ns}$ \\
\hline $\mathrm{LF} 2 \times \mathrm{L} 420$ & $6.66^{* *}$ & $-6.31^{* *}$ & $7.14^{* *}$ & -7.15 & 1.95 & $3.20 \mathrm{~ns}$ & $328.2^{*}$ \\
\hline $\mathrm{LF} 2 \times \mathrm{L} 401$ & $-5.17^{\star *}$ & 3.42 & $-17.13^{\star *}$ & $-13.32^{\star}$ & 3.77 & $-2.68 \mathrm{~ns}$ & $-27.5 \mathrm{~ns}$ \\
\hline $\mathrm{L} 420 \times \mathrm{L} 401$ & 0.76 & -3.61 & $20.94^{* *}$ & 2.50 & -1.29 & $-0.23 \mathrm{~ns}$ & $-154.6 \mathrm{~ns}$ \\
\hline
\end{tabular}

$\mathrm{ns}^{*}$ and ${ }^{* *}$ : Not- significant, significant at $5 \%$ and $1 \%$ levels of probability, respectively. 


\section{REFERENCES}

1. Amiri Oghan H, Sabaghnia N, Rameeh V, Fanaee HR, Hezarjeribi E. Univariate stability analysis of genotypexenvironment interaction of oilseed rape seed yield. Acta. Univ. Agric. Silvic. Mendel. Brun., 2016; 64(4):1-10.

2. Brandle JE, McVetty PBE. Geographical diversity parental selection and heterosis in oilseed rape. Can. J. Plant Sci., 1990; 70:935-940.

3. Diepenbrock W. Yield analysis of winter oilseed rape (Brassica napus L.): A review. Field Crops Res., 2000; 67: 35-49.

4. Downey RK, Rimer SR. Agronomic improvement in oilseed brassicas. Adv. Agron., 1993; 50:1-66.

5. Enqvist GM, Becker HC. Heterosis and epistasis in oilseed rape estimated from generation means. Euphytica, 1991; 58:31-35.

6. Faraj A, Latifi N, Soltani A, Shirani Rad AH. Effect of high temperature and supplemental irrigation in flower and pod formation in two canola (Brassica napus L.) cultivars at Mediterranean climate. Asian. J. Plant Sci. 2008; 7(4):343-351.

7. Griffing B. Concept of general combining ability in relation to diallel crossing system. Aust. J. Biol. Sci. 1956; 9: 463-493.

8. Habekotte B. Evaluation of seed yield determining factors of winter oilseed rape (Brassica napus L.) by means of crop growth modeling. Field Crops Res. 1997;54:137-151.

9. Huang Z, Laosuwan P, Machikowa T, Chen Z. Combining ability for seed yield and other characters in oilseed rape. Suranaree J. Sci. Technol. 2010;17:39-47.

10. Ishaq $M$, Raziuddin D. Combining ability analysis for maturity and plant architecture traits in intra-specific crosses of rapeseed (Brassica napus L.). Sarhad J. Agric. 2016; 32:168-176.

11. Liton MM, Rashid Bhuiyan MS, Harunur Rashid M, Estimation of Heterosis for Yield and Its Attributes in Brassica rapa L. Asian Res. J. Agric. 2017; 4(4):1-13.

12. Mahmood T, Ali M, Iqbal S, Anwar M. Genetic variability and heritability estimates in summer mustard (Brassica juncea). Asian J. Plant Sci. 2003;2(1): 77-79.

13. Marjanović - Jeromela A, Radovan J, Miladinović D. Combining abilities of oilseed rape (Brassica napus L.) varieties. Genetika 2007;39(1):53-62.

14. Nassimi AW, Raziuddin Sardar A, Naushad A. Study on heterosis in agronomic characters of oilseed rape (Brassica napus L.) using diallel. J. Agron. 2006a;5:505-508.

15. Nassimi AW, Raziuddin Sardar A, Ali N, Ali S, Bakht J. Analysis of Combining ability in Brassica napus L. lines for yield associated traits. Pak. J. Biol. Sci. 2006b; 9:23332337.

16. Qian W, Sass O, Meng J, Li M, Frauen M, Jung C.

Heterotic patterns in oilseed rape (Brassica napus L.): I. Crosses between spring and Chinese semi-winter lines. Theor. Appl. Genet. 2007;115:27-34.

17. Rameeh V. Combining ability and factor analysis in F2 diallel crosses of oilseed rape varieties. Plant Breed. Seed Sci. 2010; 62: 73-83.

18. Rameeh V. Heritability and other genetic parameters as- sessment for flowering associated stress indices in oil seed rape varieties. Int. J. Plant Breed. Genet. 2011; 5(3):268276.

19. Rameeh V. Heritability, genetic variability and correlation analysis of some important agronomic traits in rapeseed advanced lines. Cercetari Agron. Moldova 2015;48:7180 .

20. Rameeh V. Hybrid performance and combining ability analysis in rapeseed using linextester mating design. Int. J. Res. Agric. and Forestry 2017;4(8):22-28.

21. Sabaghnia N, Dehghani H, Alizadeh B, Mohghaddam M. Diallel analysis of oil content and some agronomic traits in oilseed rape (Brassica napus L.) based on the additivedominance genetic model. Aust. J. Crop Sci. 2010; 4: 609616.

22. Shen JX, Fu TD, Yang GS. Heterosis of double low selfincompatibility in oilseed rape (Brassica napus L.). Agric. Sci. China, 2002; 1:732-737.

23. Singh M, Singh L, Srivastava SBL. Combining ability analysis in Indian mustard (Brassica juncea L. Czern \& Coss). J. Oilseed Brassica 2010;1(1):23-27.

24. Teklwold A, Becker HC. Heterosis and combining ability in a diallel cross of Ethiopian mustard inbred lines. Crop Sci. 2005;45:2629-2635.

25. Wang JS, Wang XF, Zhang YF, Zhang Z, Tian JH, Li DR. Study on heterosis among subspecies or varieties in $B$. campestris L. Proceedings of the $12^{\text {th }}$ International Oilseed rape Congress Wuhan, (TRCW'07), China: Science Press USA 2007; PP:108-110.

26. Yasari E, Patwardhan AM. Physiological analysis of the growth and development of canola (Brassica napus L.) under different chemical fertilizers application. Asian. J. Plant Sci. 2006;5:745-752.

27. Zhang G, Zhu W. Genetic analyses of agronomic and seed quality traits of synthetic oilseed Brassica napusproduced from interspecific hybridization of B. campetris and B. oleracea. J. Genet. 2006;85:45-51.

28. Zhang Z, Kang SK. A SAS Program for Griffing's Diallel Analyses. Agron. J. 1997; 89:176-182. 


\section{Potencial razmnoževanja selekcioniranih linij oljne repice na nekatere pomembne kvantitativne lastnosti}

\section{IZVLEČEK}

Informacije o ocenah združevanja lastnosti potencialnih linij plemenskega materiala so pomembne za razvoj boljših sort oljne repice (Brassica napus L.). S preiskavo smo proučevali kvantitativne genetske lastnosti fenološko pomembnih lastnosti (višina rastlin, št. strokov na socvetju/rastlino in pridelek semena za osem genotipov polovično dialelnih križancev oljne repice. Rezultat dielektrične analize je pokazal značilne srednje kvadratne odklone splošnih (SPLO) in specifičnih (SPEC) lastnosti za vse proučevane lastnosti. To kaže na pomembnost delovanja aditivnega in ne-aditivnega učinka na proučevane lastnosti.

V ozkem smislu je pokazala heritabiliteta za število dni do cvetenja, trajanja cvetenja in strokov na glavnem socvetju, da je glavni aditivni učinek na proučevane lastnosti. Liniji L420 in L401 sta z značilnimi negativnimi učinki na SPLO lastnosti za število dni do cvetenja, starosti ko rastline doseže zrelost sta bili primerni za tvorjenje zgodaj zrelih kombinacij oljne repice.

Linije L41, Zafar in L22 z značilno pozitivnimi učinki na SPLO lastnosti za količino semena so bili primerni za starševsko linijo za povečanje količine semen. Križanci s statistično značilnim pozitivnim SPEC lastnostmi imajo vsaj enega starša $\mathrm{z}$ značilno pozitivno lastnostjo za to SPLO lastnost. Možne najboljše kombinacije križanj so se pokazali križanci L41×L22, L41×LF2, Zafar $\times$ L22 in Zafar $\times$ L420, ki so imeli pridelek semena 3421,7, 3400, 3348,1 in 3311,3 kg ha-1.

Omenjeni križanci so najboljši rekombinanti za visok pridelek semena in druge rastne lastnosti v naslednjih generacijah segregacijske selekcije.

Ključne besede: oljna repica, križanci, aditivni učinki, stopnja dominantnosti, sposobnost združevanja lastnosti, heritabiliteta, pridelek 